\section{Kurılgan Ekonomilerde Finansal Gelişme Düzeyinin Ekonomik Büyüme Üzerindeki Etkisi}

\author{
Faruk Mike $^{\mathrm{a}}$, Ali Eren Alper ${ }^{\mathrm{b}}$
}

Öz: Bu çalışma, Morgan Stanley tarafından yapılan ülke sınıflandırmasından hareketle, kırılgan ekonomiler grubuna dahil olan beş ülke için finansal gelişme düzeyinin ekonomik büyüme üzerindeki etkisini araştırmayı amaçlamaktadır. 1980-2017 dönemleri için yıllık gözlemlerin dahil edildiği çalışmada, Shin eşbütünleşme, Fourier Shin eşbütünleşme ve Toda-Yamamoto nedensellik analizleri gerçekleştirilmiştir. Fourier Shin eşbütünleşme testinden elde edilen bulgular Endonezya dışında yer alan dört ülke (Brezilya, Güney Afrika, Hindistan ve Türkiye) için ekonomik büyüme ile finansal gelişme, sabit sermaye stoku ve insani gelişme endeksi değiş̧enleri arasında uzun dönemli bir ilişkinin varlığını ortaya koymaktadır. Diğer taraftan Shin eşbütünleşme testi ise Brezilya, Endonezya ve Güney Afrika için eşbütünleşme ilişkisinin varlığına işaret etmektedir. Dinamik en küçük kareler tahmincisi, Brezilya dışında yer alan ülkelerin tamamı (Endonezya, Hindistan, Güney Afrika ve Türkiye) için finansal gelişmenin ekonomik büyüme üzerinde pozitif ve istatistiksel olarak anlamlı katsayılara sahip olduğunu ortaya koymaktadır. Bununla birlikte Toda-Yamamoto nedensellik analizi ile sadece Endonezya ve Güney Afrika ülkeleri için finansal gelişme düzeyinden ekonomik büyümeye doğru tek yönlü nedensellik ilişkisinin varlığı tespit edilmiştir. Elde edilen bulgular temel olarak finansal gelişme düzeyinin kırılgan ekonomilerin sürdürülebilir büyüme süreçlerinde oldukça önemli bir parametre olduğuna işaret etmektedir.

\section{The Effect of Financial Development on Economic Growth in Fragile Economics}

\begin{abstract}
This study aims to analyse the impact of financial development on economic growth for fragile five economies, which are based on the country classification by Morgan Stanley. Accordingly, Shin cointegration, Fourier Shin cointegration, and Toda-Yamamoto causality analyses were performed for the annual observations from 1980 to 2017. Fourier Shin cointegration test results reveal the existence of a long-run relationship between economic growth and financial development, capital stock, and human development index for four countries, namely Brazil, India, South Africa, and Turkey. On the other hand, Shin cointegration test results indicate the existence of cointegration relationship between series for Brazil, Indonesia, and South Africa. Dynamic Least Squares estimator shows that financial development has positive and statistically significant coefficients for four countries, namely India, Indonesia, South Africa, and Turkey (except Brazil). Finally, Toda-Yamamoto causality analyses reveal that there is only a unidirectional causality running from financial development to economic growth for Indonesia and South Africa. The findings reveal that the level of financial development is a significant parameter in fragile economies' sustainable growth processes.
\end{abstract}

Anahtar Sözcükler: Finansal Gelişme, Ekonomik Büyüme, Kırılgan Ekonomiler, Fourier Eşbütünleşme Testi, Nedensellik Analizi

JEL: C32, G15, O40

$\begin{array}{ll}\text { Geliş } & : 27 \text { Temmuz } 2020 \\ \text { Düzeltme } & : 13 \text { Ekim } 2020 \\ \text { Kabul } & : 27 \text { Kasım 2020 } \\ \text { Tür } & : \text { Araştırma }\end{array}$

Keywords: Financial Development, Economic Growth, Fragile Economics, Fourier Cointegration Test, Causality Analysis

JEL: C32, G15, O40 $\begin{array}{ll}\text { Received } & : 27 \text { July } 2020 \\ \text { Accepted } & : 27 \text { November } 2020\end{array}$

Type : Research

a Asst. Prof., PhD., Hakkari University, Faculty of Economics and Administrative Sciences, Department of Economics, Hakkari, Turkiye, farukmike@hakkari.edu.tr (ORCID ID: 0000-0002-9194-1679)

b Assoc. Prof., PhD., Nigde Omer Halisdemir University, Faculty of Economics and Administrative Sciences, Department of Public Finance, Nigde, Turkiye, alierenalper@gmail.com (ORCID ID: 0000-0003-0008-1202) 


\section{Giriş}

Sürdürülebilir bir ekonomik büyümenin temel belirleyicilerini açıklamaya yönelik olarak literatürde uzun yıllardır oldukça önemli bir araştırma alanının geliştiği gözlemlenmektedir. Söz konusu literatürün büyük çoğunluğu makroekonomik istikrar, eşitsizlik, kurumsal gelişme, piyasa başarısızlıkları, gelir ve servet gibi temel değişkenler üzerine odaklanmaktadır (Christopoulos ve Tsionas, 2004: 55-56). Ancak son dönemlerde, bu faktörlerin yanı sıra, özellikle finansal piyasaların ekonomik büyüme süreci üzerindeki rolü ile ilgili olarak yoğun bir tartışma alanının da oluştuğu dikkatleri çekmektedir. Bu durum özellikle ekonomik büyüme süreçlerinde dış finansman kaynă̆ının önemli bir rol oynadığı gelişmekte olan ülke ekonomileri için vazgeçilmez bir öneme sahiptir.

Literatürde temel olarak finansal gelişmenin ekonomik büyüme üzerinde pozitif etkilere sahip olduğu genel kabul gören bir yaklaşımdır. Levine $(1997,2005)$ söz konusu pozitif etkileri beş başlık altında toplamaktadır: (i) Kaynak dağııımında etkinliği sağlaması; (ii) kurumsal yönetimi güçlendirmesi; (iii) riske karşı korunmayı artırması ve portföy çeşitlendirmesini teşvik etmesi; (iv) tasarrufların yatıım projeleri için daha esnek bir şekilde hareket etmesine olanak tanıması ve son olarak (v) mal ve hizmet alışverişini kolaylaştırması. Ancak diğer taraftan, bu olumlu etkilerin hangi ölçüde gerçekleşeceği, ülkelerin sahip olduğu finansal gelişme seviyeleri, ekonomik kalkınma düzeyleri ve kurumların kaliteleri gibi temel faktörlere bağlı olarak farklılık göstermektedir (Arestis, Demetriades ve Luintel, 2001: 16). Bu anlamda yapılan araştırmalar finansal gelişme ve ekonomik büyüme arasındaki ilişkinin yönü ve doğası hakkında ampirik olarak farklı sonuçlara işaret etmektedir (Bhattacharya ve Sivasubramanian, 2003: 925).

Teorik olarak finansal gelişme ve ekonomik büyümeyi açıklamaya yönelik olarak literatürde üç temel yaklaşım öne sürülmektedir. Bu yaklaşımlardan ilki, finansal gelişmenin ekonomik büyüme üzerinde önemli bir role sahip olduğunu ifade eden "finans kaynaklı büyüme" hipotezidir. Bu hipoteze göre finansal gelişme, sermayenin etkin dağııımını sağlaması, tasarrufları güvenilir unsurlar ile piyasaya yönlendirmesi, bilgi ve işlem maliyetlerini azaltması gibi çeşitli kanallar vasıtasıyla ekonomik büyümeyi teşvik edici etkilere sahiptir (Akinlo ve Egbetunde, 2010: 19). Özellikle potansiyel yatırım fırsatları için gerekli olan fon ihtiyacını karşılaması, ekonomik büyüme üzerindeki en önemli katkısı olarak kabul edilmektedir (Colombage, 2009: 339). Bu yaklaşım ayrıca piyasaya sağladığı finansal girdiler sayesinde literatürde "arz yönlü yaklaşım" olarak da ifade edilmektedir (Patrick, 1966: 174).

İkinci yaklaşım ise, finans kaynaklı büyüme hipotezinin aksine, ekonomik büyümenin finansal gelişme sürecine katkı sağladığını ifade eden "büyümeye dayalı finansman" hipotezidir (Akinlo ve Egbetunde, 2010: 19). Robinson (1952), Lucas (1988) ve Stern (1989) gibi önemli iktisatçıların vurguladığı bu yaklaşım, temel olarak, finansal gelişme sürecinin ekonomik büyüme için önemli bir belirleyici olmadığını, aksine finansal gelişmenin ekonomik büyüme potansiyeline bağı olarak gelişim gösterdiğini iddia etmektedir. Ekonomik büyümenin finansal varlık talebini artırdığı varsayımıyla hareket eden bu görüş (Ghirmay, 2004: 416), literatürde ayrıca "talep yönlü yaklaşım" olarak da isimlendirilmektedir (Patrick, 1966: 174-175).

Üçüncü ve son yaklaşım ise ekonomik büyüme ve finansal gelişme arasında iki yönlü etkileşimin varlığını ortaya koyan "geri dönüşüm (feedback)" hipotezidir. Bu hipoteze göre ekonomik büyüme, finansal piyasalara katılım sürecinde karşılaşılan sabit maliyetlerin azaltılmasına yardımcı olarak, daha fazla oranda finansal kurumun oluşmasını ve geliştirilmesini teşvik etmektedir (Ghirmay, 2004: 420). Finansal kurum sayılarında yaşanan artışlar ise beraberinde, hanehalkı tasarruflarının daha yüksek oranda yatırım sürecine dahil edilmesi ve nihai olarak ekonomik büyümeyi artırması imkanı tanımaktadır ${ }^{1}$.

Bu çalışma Morgan Stanley tarafından kategorize edilen "kırılgan" ülkeler için finansal gelişmenin ekonomik büyüme üzerindeki etkilerini incelenmeyi amaçlamaktadır. 1980-2017 dönemleri için yıllık gözlemlerin dahil edildiği çalışmada Shin eşbütünleşme, Fourier Shin eşbütünleşme ve Toda-Yamamoto nedensellik analizleri gerçekleştirilecektir. Bu doğrultuda çalışmada izlenecek planlama sırasıyla şu şekildedir: İkinci bölümde kırılgan ekonomilerin makroekonomik performansları ile ilgili bazı önemli bilgilere yer verilecektir. Üçüncü bölümde konuya özgü literatür taraması açıklanacaktır. Dördüncü bölüm veri seti ve beşinci bölüm ekonometrik metodolojiden oluşmaktadır. Analiz bulgularının tartışılacağı altıncı bölümün ardından, çalışma sonuç ve değerlendirme bölümü ile tamamlanacaktır. 


\section{Kırılgan Ekonomilerin Makroekonomik Performansları}

Kırılgan ekonomi sınıflandırması ilk kez 2013 yılında Morgan Stanley tarafından gerçekleştirilmiştir. Bu sınıflandırmanın temelinde, büyüme hedeflerini finanse etmek için güvenilir olmayan yatırımlara oldukça bağımlı olan ekonomilerin tespit edilmesi yer almaktadır (Chadwick, 2019: 251). Bu doğrultuda söz konusu sınıflandırmaya dahil olan ilk ülke grubu sırasıyla Brezilya, Endonezya, Güney Afrika, Hindistan ve Türkiye şeklindedir. Ancak ülkelerin makroekonomik performanslarında gösterdikleri gelişmeleri takiben, söz konusu sınıflandırmada zamanla değişiklikler meydana gelmektedir. Yine Morgan Stanley tarafından 2016 yılında yapılan kırılgan ekonomi sınıflandırmasında Brezilya ve Hindistan'ın yerini, Kolombiya ve Meksika almıştır. Bu çalışmada sadece 2013 yılındaki sınıflandırma dikkate alınmakta ve veri kısıtı bulunmayan tüm ülkeler için ampirik analizlerin gerçekleştirilmesi planlanmaktadır.

2008 yılında küresel ölçekte meydana gelen finansal kriz ve sonrasında gelişmiş ülkelerde girişilen ekonomik toparlanma çabaları, uluslararası yatırımcıların sahip oldukları sermayeleri gelişen piyasa ekonomilerinden daha güvenilir ekonomilere (Amerika Birleşik Devletleri gibi) aktarmalarına neden olmuştur. Yabancı sermaye arzında yaşanan bu daralma, özellikle kırılgan ekonomilerin para birimlerinde önemli değer kayıpları meydana getirmiştir. Uluslararası Para Fonu (IMF) verilerine göre 2013-2019 yılları arasında kırılgan ekonomiler içinde para birimi değer kayıpları sırasıyla ve yaklaşık olarak Türkiye'de \%298, Brezilya'da \%182, Güney Afrika'da \%149, Endonezya'da \%135 ve Hindistan'da \%120 düzeylerinde gerçekleşmiştir.

Kırılgan ekonomilerin makroekonomik performanslarını ortaya koymaya yönelik olarak dikkat edilmesi gereken parametrelerden bir diğeri ise enflasyon oranlarındaki değişimlerdir. Çalışmanın Ek kısmında yer alan Tablo A2'deki verilere göre, 2013 yılından itibaren enflasyon oranları konusunda en olumsuz performansı sergileyen ülkenin Türkiye olduğu dikkat çekmektedir. 2013 yılında ortalama \%7,49 düzeylerinde olan enflasyon oranı, 2018 yılında ortalama \%16,33 ve 2019 yılında ise ortalama \%15,18 düzeylerinde gerçekleşmiştir. Buna karşın diğer ülkeler enflasyon oranlarında azalma eğilimi göstermeyi başarmışlardır.

Enflasyon oranlarının yanı sıra cari işlemler (Tablo A3) ve bütçe dengesindeki değişimler (Tablo A4) de kırılgan ekonomiler için yakından takip edilen iki önemli parametredir. 2013 ve 2019 yılı verileri bir arada değerlendirildiğinde, her iki parametrede olumlu trendin yaşandığı sadece tek bir ülke bulunmaktadır: Endonezya. Bununla birlikte Türkiye, cari işlemler fazlası veren (2019 yılı itibariyle) tek ülke konumundadır.

Önemli yatırım projeleri için döviz girdisi ihtiyacı bulunan kırılgan ekonomilerin, temel makroekonomik göstergeler üzerinde gösterdiği bu performanslar son olarak büyüme rakamları ile de uyum göstermektedir. Tablo A1'de yer alan verilere göre, Endonezya dışındaki ekonomilerin tamamı son yedi yıllık süre içerisinde istikrarsız bir büyüme performansı sergilemiş ve bazı ülkelerin (Brezilya ve Türkiye) büyüme oranlarında önemli düşüşler meydana gelmiştir. Bu durum özellikle söz konusu ülkelerdeki politika yapıcılar için finansal gelişme ve ekonomik büyüme arasındaki ilişkinin tespit edilmesini daha önemli bir hale getirmektedir.

\section{Literatür Taraması}

Finansal gelişme ve ekonomik büyüme arasındaki ilişkiyi açıklamaya yönelik geliştirilen teorik yaklaşımlar 20. yüzyılın başlarına kadar uzanan bir geçmişe sahip bulunsa da, temel olarak ilk ampirik katkının Goldsmith (1969) tarafında gerçekleştirildiği kabul edilmektedir (Bhattacharya ve Sivasubramania, 2003; Caporale, Rault, Sova ve Sova, 2015). Goldsmith (1969) çalışmasında finansal gelişme düzeyi ile kişi başına düşen gayrisafi milli hasıla arasında pozitif bir ilişkinin varlığını ilk kez ampirik olarak ortaya koymuştur. Bu çalışmayı takiben literatürde reel ve finansal piyasalar arasındaki nedensellik ilişkisini açıklama anlamında oldukça yoğun bir araştırma sürecinin önü açılmıştır. Bu çalışmalardan bazıları Tablo 1'de yer almaktadır. Elde edilen bulgular ise mevcut durumda ortak bir görüş birliğinin sağlanamadığını ortaya koymaktadır.

Kırılgan ekonomiler özelinde incelendiğinde ise literatürde söz konusu ülkeleri bir bütün olarak inceleyen az sayıda çalışmanın bulunduğu dikkat çekmektedir. Bu çalışmalardan Hayaloğlu (2015), kırılgan beş ekonomi için 1990-2012 dönemlerini dinamik panel veri analizi ile incelemiştir. Genelleştirilmiş 
Momentler Metodu (GMM) tahmincisinden elde edilen bulgular, söz konusu ülke grubu için finansal gelişmenin ekonomik büyüme üzerinde pozitif katkı sağladığını ortaya koymaktadır. Helhel (2018) ise benzer ülke grubu için 2002-2016 dönemlerini panel eşbütünleşme ve panel VECM nedensellik analizleri ile test etmiştir. Pedroni eşbütünleşme analizi ile söz konusu seriler arasında uzun dönemli ilişkinin varlığı tespit edilmiştir. Panel VECM nedensellik analizi sonuçları ise ekonomik büyümeden finansal gelişme düzeyine doğru tek yönlü nedensellik ilişkisinin varlı̆ı̆na işaret etmektedir. Son olarak DOLS ve FMOLS tahmincilerinden elde edilen bulgular ise ekonomik büyümenin finansal geliş̧me endeksi üzerinde pozitif ve istatistiksel olarak anlamlı bir etkiye sahip olduğunu ortaya koymaktadır. Çalışmada ayrıca finansal yatırımlara yönelik kredi havuzundaki genişlemelerin ekonomik büyümeyi desteklemediği bulgularına ulaşıımıştır.

Bununla birlikte kırılgan ekonomiler için yapılan ampirik araştırmaların çoğunlukla bireysel ülke analizleri ile gerçekleştirildiği söylenebilir. Bu çalışmalardan Stefani (2007) ve Moyo, Khobai, Kolisi ve Mbeki (2018) "Brezilya"; Soedarmono, Hasan ve Arsyad (2017) ve Sumarni (2019) "Endonezya"; Nyasha ve Odhiambo (2015) ve Gondo (2009) "Güney Afrika"; Bhattacharya ve Sivasubramanian (2003), Singh (2008) ve Lenka ve Sharma (2020) "Hindistan" ve son olarak Halicioglu (2007), Kaya, Bektaş ve Feridun (2011) ve Soytaş ve Küçükkaya (2011) "Türkiye" için finansal gelişme ve ekonomik büyüme arasındaki ilişkiyi incelemişlerdir. Elde edilen bulgular karışık niteliktedir.

Bu çalışmalardan, örneğin, Hindistan için 1970/1971-1998/1999 dönemlerini yıllık gözlemler doğrultusunda Granger nedensellik analizi ile inceleyen Bhattacharya ve Sivasubramanian (2003), finansal gelişmeden (M3 para arzı) gayrisafi yurtiçi hasıla düzeyine doğru tek yönlü nedensellik ilişkisinin bulunduğunu tespit etmiştir. Stefani (2007), Brezilya için 1986-2006 dönemlerini çeyreklik gözlemler doğrultusunda VAR temelli Granger nedensellik analizi ile incelemiş ve finansal gelişmenin ekonomik büyüme üzerinde itici bir güç olduğu sonucuna ulaşmıştır. Soytaş ve Küçükkaya (2011), Türkiye için 1991-2005 dönemlerini çeyreklik gözlemler doğrultusunda Toda-Yamamoto nedensellik analizi ile incelemiş ve ekonomik büyüme ve finansal gelişme arasında herhangi bir önemli ilişkinin bulunmadığı bulgularına ulaşmıştır. Nyasha ve Odhiambo (2015), Güney Afrika için 1980-2012 dönemlerini yıllık gözlemler doğrultusunda ARDL sınır testi yaklaşımı ile incelemiştir. Elde edilen bulgular Güney Afrika'daki reel sektör gelişiminin büyük oranda hisse senedi piyasasındaki gelişmelere bağlı olarak gerçekleştiğini ortaya koymaktadır. Sumarni (2019), Endonezya için 2005-2016 dönemlerini çeyreklik gözlemler doğrultusunda ARDL sınır testi yaklaşımı ile incelemiştir. Çalışmaya dahil edilen üç finansal gelişme göstergesinden sadece ticari bankaların finansal varlık değişkeninin ekonomik büyüme üzerinde pozitif ve istatistiksel olarak anlamlı bir etkiye sahip olduğu bulguları elde dilmiştir. Genel olarak kırılgan ekonomiler için elde edilen bulgular, Tablo 1'de belirli ülke ve ülke grupları için gerçekleştirilen analiz sonuçlarına benzerlik göstermektedir.

Tablo 1. Seçili Ampirik Literatür

\begin{tabular}{|c|c|c|c|}
\hline Yazar(lar) & Ülke/Dönem & Yöntem(ler) & Sonuç \\
\hline $\begin{array}{l}\text { Demetriades ve } \\
\text { Hussein (1996) }\end{array}$ & $\begin{array}{c}16 \text { Ülke } \\
(1960-1990)\end{array}$ & $\begin{array}{l}\text {-Engel-Granger ve } \\
\text { Johansen Eşbütünleşme } \\
\text {-Granger Nedensellik }\end{array}$ & $\begin{array}{l}\text { Finansal gelişme, sadece } 3 \text { ülke için (Honduras, } \\
\text { İspanya ve Sri Lanka) ekonomik büyüme sürecinin } \\
\text { öncü bir göstergedir. }\end{array}$ \\
\hline Arestis vd. (2001) & $\begin{array}{l}5 \text { Gelişmiş } \\
\text { Ekonomi } \\
(1972: 2-1998: 1)\end{array}$ & -Johansen Eşbütünleşme & $\begin{array}{l}\text { Banka temelli finansal sistemler, ekonomik } \\
\text { büyümeye sağladıkları katkı bakımından, sermaye } \\
\text { piyasası temelli (hisse senedi piyasası) sistemlerden } \\
\text { daha değerlidir. }\end{array}$ \\
\hline Chang (2002) & $\begin{array}{c}\text { Çin } \\
(1987: 1-1994: 4)\end{array}$ & $\begin{array}{l}\text {-Johansen Eşbütünleşme } \\
\text {-Granger Nedensellik }\end{array}$ & $\begin{array}{l}\text { Finansal gelişmenin ekonomik büyüme üzerindeki } \\
\text { etkisi, dışa açıklık derecesiyle dolaylı olarak } \\
\text { gerçekleşmektedir. }\end{array}$ \\
\hline Dawson (2003) & $\begin{array}{l}13 \text { Orta ve Doğu } \\
\text { Avrupa Ülkesi } \\
\text { (1994-1999) }\end{array}$ & $\begin{array}{l}\text {-Sabit Etkiler } \\
\text {-Rassal Etkiler }\end{array}$ & $\begin{array}{l}\text { Finansal gelişme, ekonomik büyüme üzerinde pozitif } \\
\text { fakat istatistiksel olarak anlamsız bir etkiye sahiptir. }\end{array}$ \\
\hline $\begin{array}{l}\text { Christopoulos ve } \\
\text { Tsionas (2004) }\end{array}$ & $\begin{array}{l}10 \text { Gelişmekte } \\
\text { Olan Ülke } \\
(1970-2000)\end{array}$ & $\begin{array}{l}\text {-Panel (Fisher) } \\
\text { Eşbütünleşme } \\
\text {-Panel Nedensellik }\end{array}$ & $\begin{array}{l}\text { Finansal borçlar, ekonomik büyüme üzerinde pozitif } \\
\text { ve istatistiksel olarak anlamlı bir etkiye sahiptir. } \\
\text { Ayrıca finansal gelişmeden ekonomik büyümeye } \\
\text { doğru tek yönlü nedensellik ilişkisi bulunmaktadır. }\end{array}$ \\
\hline
\end{tabular}


Tablo 1. Seçili Ampirik Literatür (Devamı)

\begin{tabular}{|c|c|c|c|}
\hline Yazar(lar) & Ülke/Dönem & Yöntem(ler) & Sonuç \\
\hline Ghirmay (2004) & $\begin{array}{l}13 \text { Sahra Altı } \\
\text { Afrika Ülkesi }\end{array}$ & $\begin{array}{l}\text {-Johansen Eşbütünleşme } \\
\text {-Granger Nedensellik }\end{array}$ & $\begin{array}{l}8 \text { ülke için finansal gelişmeden ekonomik büyümeye } \\
\text { doğru nedensellik ilişkisi bulunmaktadır. Bu durum } \\
\text { Afrika ülkelerinin finansal sistemlerini geliştirerek } \\
\text { ekonomik büyümelerini hızlandırabileceğine işaret } \\
\text { etmektedir. }\end{array}$ \\
\hline $\begin{array}{l}\text { Chang ve Caudill } \\
\text { (2005) }\end{array}$ & $\begin{array}{c}\text { Tayvan } \\
(1862-1998)\end{array}$ & $\begin{array}{l}\text {-Johansen } \\
\text { Eşbütünleşme } \\
\text {-Granger Nedensellik }\end{array}$ & $\begin{array}{l}\text { Finansal gelişmeden ekonomik büyümeye doğru tek } \\
\text { yönlü nedensellik ilişkisi bulunmakta ve bu sonuç } \\
\text { Tayvan için arz yönlü hipotezi doğrulamaktadır. }\end{array}$ \\
\hline $\begin{array}{l}\text { Baliamoune-Lutz } \\
\text { (2008) }\end{array}$ & $\begin{array}{l}3 \text { Kuzey Afrika } \\
\text { Ülkesi } \\
(1960-2001)\end{array}$ & $\begin{array}{l}\text {-Johansen Eşbütünleşme } \\
\text {-Granger Nedensellik }\end{array}$ & $\begin{array}{l}\text { Likit yükümlülükler dikkate alındığında, finansal } \\
\text { gelişme söz konusu ülkeler için ekonomik } \\
\text { kalkınmaya öncülük etmektedir. }\end{array}$ \\
\hline $\begin{array}{l}\text { Colombage } \\
(2009)\end{array}$ & $\begin{array}{l}5 \text { Sanayileşmiş } \\
\text { Ekonomi } \\
(1995: 1-2007: 1)\end{array}$ & $\begin{array}{l}\text {-Johansen Eşbütünleşme } \\
\text {-Granger Nedensellik }\end{array}$ & $\begin{array}{l}\text { Finansal piyasalardaki gelişmeler, Kanada dışındaki } \\
\text { dört ülke için, ekonomik büyümeye katkı } \\
\text { sağlamaktadır. }\end{array}$ \\
\hline $\begin{array}{l}\text { Akinlo ve } \\
\text { Egbetunde (2010) }\end{array}$ & $\begin{array}{l}10 \text { Sahra Altı } \\
\text { Afrika Ülkesi } \\
(1980-2005)\end{array}$ & $\begin{array}{l}\text {-Johansen Eşbütünleşme } \\
\text {-Granger Nedensellik }\end{array}$ & $\begin{array}{l}\text { Finansal sektörlerin dış dünyaya daha fazla oranda } \\
\text { açılması, söz konusu ülkelerin ekonomik } \\
\text { büyümelerine katkı sağlayacaktır. }\end{array}$ \\
\hline Dawson (2010) & $\begin{array}{l}58 \text { Az Gelişmiş } \\
\text { Ülke } \\
(1960-2002)\end{array}$ & $\begin{array}{l}\text {-Panel (Pedroni) } \\
\text { Eşbütünleşme }\end{array}$ & $\begin{array}{l}\text { Finansal gelişme ve ekonomik büyüme arasında } \\
\text { pozitif ve istatistiksel olarak anlamlı bir ilişki } \\
\text { bulunmaktadır. }\end{array}$ \\
\hline $\begin{array}{l}\text { Anwar ve Nguyen } \\
(2011)\end{array}$ & $\begin{array}{c}\text { Vietnam'a ait } 61 \\
\text { Bölge } \\
(1997-2006) \\
\end{array}$ & $-G M M$ & $\begin{array}{l}\text { Yüksek kredi oranları (finansal gelişme) Vietnam'ın } \\
\text { ekonomik büyümesi üzerinde önemli katkılar } \\
\text { sağlamaktadır. }\end{array}$ \\
\hline $\begin{array}{l}\text { Kar, Nazlıoğlu ve } \\
\text { Ağır (2011) }\end{array}$ & $\begin{array}{l}15 \text { MENA Ülkesi } \\
\text { (1980-2007) }\end{array}$ & $\begin{array}{l}\text {-Panel (Kónya) } \\
\text { Nedensellik }\end{array}$ & $\begin{array}{l}\text { Finansal gelişme, MENA ülkelerinin ekonomik } \\
\text { büyüme süreçleri için önemli bir belirleyici değildir. }\end{array}$ \\
\hline $\begin{array}{l}\text { Uddin, Sjö ve } \\
\text { Shahbaz (2013) }\end{array}$ & $\begin{array}{c}\text { Kenya } \\
(1971-2011)\end{array}$ & $\begin{array}{l}\text {-ARDL } \\
\text {-Gregory ve Hansen } \\
\text { Eşbütünleşme }\end{array}$ & $\begin{array}{l}\text { Finansal sektör gelişimleri Kenya'nın ekonomik } \\
\text { büyümesi üzerinde pozitif etkilere sahiptir. }\end{array}$ \\
\hline $\begin{array}{l}\text { Caporale vd. } \\
(2015)\end{array}$ & $\begin{array}{l}10 \text { Yeni Avrupa } \\
\text { Birliği Ülkesi } \\
(1994-2007)\end{array}$ & $-G M M$ & $\begin{array}{l}\text { Bu ülkelerde hisse senedi ve kredi piyasaları yeterli } \\
\text { düzeyde gelişmediği için ekonomik büyüme } \\
\text { üzerindeki katkıları da sınırlıdır. }\end{array}$ \\
\hline $\begin{array}{l}\text { Shahbaz, Rehman } \\
\text { ve Muzaffar } \\
\text { (2015) }\end{array}$ & $\begin{array}{l}\text { Bangladeş } \\
(1976-2012)\end{array}$ & $\begin{array}{l}\text {-Bayer-Hanck } \\
\text { Eşbütünleşme } \\
\text {-Granger Nedensellik }\end{array}$ & $\begin{array}{l}\text { Finansal gelişme, ticari açıklık ve işgücü miktarı, } \\
\text { Bangladeş'in ekonomik büyüme performansı } \\
\text { üzerinde artış sağlamaktadır. }\end{array}$ \\
\hline $\begin{array}{l}\text { Pradhan, Arvin, } \\
\text { Hall ve Nair } \\
\text { (2016) }\end{array}$ & $\begin{array}{l}18 \text { Eurozone } \\
\text { Ülkesi } \\
(1961-2013)\end{array}$ & $\begin{array}{l}\text {-Panel Granger } \\
\text { Nedensellik }\end{array}$ & $\begin{array}{l}\text { Finansal gelişme ve yenilik kapasitesindeki artışlar, } \\
\text { uzun dönem ekonomik büyüme üzerinde önemli } \\
\text { katkılar sağlamaktadır. }\end{array}$ \\
\hline $\begin{array}{l}\text { Durusu-Ciftci, } \\
\text { Ispir ve Yetkiner } \\
\text { (2017) }\end{array}$ & $\begin{array}{c}40 \text { Ülke } \\
(1989-2011)\end{array}$ & $\begin{array}{l}\text {-Panel Bootstrap } \\
\text { Eşbütünleşme }\end{array}$ & $\begin{array}{l}\text { Kredi temelli finansal sistemler, ekonomik } \\
\text { büyümeye sağladıkları katkı bakımından, sermaye } \\
\text { piyasası temelli (hisse senedi piyasası) sistemlerden } \\
\text { daha değerlidir. }\end{array}$ \\
\hline $\begin{array}{l}\text { Ehigiamusoe ve } \\
\text { Lean (2018) }\end{array}$ & $\begin{array}{l}16 \text { Batı Afrika } \\
\text { Ülkesi } \\
(1980-2014)\end{array}$ & $\begin{array}{l}\text {-4 Farklı Panel Regresyon } \\
\text { Modeli } \\
\text {-SUR Tahmincisi }\end{array}$ & $\begin{array}{l}\text { Finansal gelişme, } 10 \text { Batı Afrika ülkesi için, ekonomik } \\
\text { büyüme üzerinde pozitif etkiye sahiptir. }\end{array}$ \\
\hline $\begin{array}{l}\text { Asteriou ve } \\
\text { Spanos (2019) }\end{array}$ & $\begin{array}{l}26 \text { Avrupa Birliği } \\
\text { Ülkesi } \\
(1990-2016)\end{array}$ & -Sabit Etkiler & $\begin{array}{l}2008 \text { krizi öncesinde finansal gelişme Avrupa } \\
\text { ülkelerinin ekonomik büyümelerini destekliyorken, } \\
\text { kriz sonrasında ekonomik faaliyetleri büyük oranda } \\
\text { engellemiştir. }\end{array}$ \\
\hline
\end{tabular}

Not: Tabloda yer alan bazı kısaltmalar şu şekildedir: ARDL: Gecikmesi Dağıtılmış Otoregresif Sınır Testi, GMM: Genellleştirilmiş Momentler Metodu, SUR: Görünürde İlişkisiz Regresyon, VECM: Vektör Hata Düzeltme Modeli. 


\section{Veri Seti}

Bu çalışma, kırılgan ekonomiler için finansal gelişme düzeyinin ekonomik büyüme üzerindeki etkisini 1980-2017 yıllık gözlemler doğrultusunda incelemeyi amaçlamaktadır. Çalışmada uygulanacak model, 1 numaralı denklemde yer almaktadır. Model tercihi konusunda Botev, Egert ve Jawardi (2019)'un çalışmasından yararlanılmıştır:

$$
\ln Y_{t}=a_{0}+\beta_{1} \ln K_{t}+\beta_{2} \operatorname{lnOPEN} N_{t}+\beta_{3} \ln F D_{t}+\beta_{4} \ln H C I_{t}+\varepsilon_{t}
$$

Eşitlikte bağımlı değişken olarak yer alan $Y_{t}$ değeri ekonomik büyümeyi ifade etmektedir ve kişi başına düşen reel gayrisafi yurtiçi hasıla verisi ile temsil edilmektedir. Bağımsız değişkenlerden $K_{t}$ toplam sabit sermaye stokunu (GSYiH'nın \%'si), OPEN $N_{t}$ dışa açıklık oranını [(ihracat+ithalat)/GSYiH], $F D_{t}$ finansal gelişme endeksini ve son olarak $\mathrm{HCI}_{t}$ ise insani gelişme endeksini ifade etmektedir. Ayrıca $a_{0}$ değeri sabit terimi ve $\varepsilon_{t}$ değeri ise hata terimine işaret etmektedir. $\beta_{1}, \beta_{2}, \beta_{3}$ ve $\beta_{4}$ parametreleri ise sırasıyla toplam sabit sermaye stoku, dışa açıklık oranı, finansal gelişme endeksi ve insani gelişme endeksi değişkenlerinin ekonomik büyüme üzerindeki esneklik katsayılarını yansıtmaktadır. Modelde yer alan finansal gelişme endeksi serisi Uluslararası Para Fonu (IMF-IFS) veri tabanı, insani gelişme endeksi serisi Penn World Table 9.1 veri tabanı ve geriye kalan serilen tamamı ise Dünya Bankası veri tabanından temin edilmiştir. Tüm seriler logaritmaları alınarak çalışmaya dahil edilmiştir.

Literatürde finansal gelişmenin çeşitli ekonomik büyüklükler (ekonomik büyüme, eşitsizlik, finansal istikrar vb.) üzerindeki etkilerini açıklamaya yönelik olarak çok sayıda çalışma yer almaktadır. Söz konusu çalışmalar temel olarak finansal gelişmeyi ifade eden iki değişken üzerine odaklanmaktadır: Özel sektör kredilerinin GSYiH'ya oranı veya hisse senedi piyasası değerinin GSYiH'ya oranı. Ancak bu göstergeler, finansal gelişmenin çok boyutlu karmaşık doğasını tam anlamıyla açıklayamamaktadır. Bu nedenle ülkelerin finansal gelişme düzeylerini çok boyutlu bir şekilde dikkate alan ve IMF tarafından geliştirilen "finansal gelişme endeksinin" kullanılması daha doğru bir yaklaşım olarak kabul edilmektedir (Sahay vd., 2015).

Çalışmaya dahil edilen ülkeler, Morgan Stanley tarafından 2013 yılında gerçekleştirilen kırılgan ekonomiler sınıflandırılmasından hareketle belirlenmiştir. Söz konusu ülkeler sırasıyla Brezilya, Endonezya, Güney Afrika, Hindistan ve Türkiye'den oluşmaktadır. Çalışma dönemi için ise finansal gelişme sürecinin büyük oranda gerçekleşmeye başladığı kabul edilen 1980 yılı başlangıç dönemi olarak tercih edilmiştir. İnsani gelişme endeksinin 2017 yılına kadar mevcut bulunması ise çalışma döneminin bitiş sınırlarını belirlemektedir.

\section{Ekonometrik Metodoloji}

\subsection{Birim Kök Testi}

Serilerin durağan olmaması şokların, uzun dönem katsayılar üzerinde kalıcı etkilere sahip olmasına neden olmaktadır. Bu nedenle de regresyon analizine başlamadan önce serilerin bütünleşme derecelerinin tespit edilmesi önem taşımaktadır. Bu çalışmada değişkenlerin bütünleşme derecelerinin tespiti için Becker, Enders ve Lee (2006) tarafından geliştirilen Fourier KPSS (FKPSS) durağanlık testi kullanılacaktır. FKPSS durağanlık testi sadece keskin (sharp) yapısal değişimleri değil aynı zamanda yumuşak (smooth) değişimleri de tespit edebilmekte ve yapısal değişimlerin tarihi, sayısı ve formu, testin güvenilirliğini etkilememektedir (Yılancı, 2017).

Becker vd. (2006) çalışmasında Denklem 2 ve 3'de belirtilen veri yaratma sürecini dikkate almıştır.

$$
\begin{aligned}
& y_{t}=X_{t}^{\prime} \beta+Z_{t}^{\prime} \gamma+r_{t}++\varepsilon_{t} \\
& r_{t}=r_{t-1}+u_{t}
\end{aligned}
$$


Burada $\varepsilon_{t}$ durağan hata terimini, $u_{t}$ ise $\sigma_{u}^{2}$ varyansla bağımsız, benzer dağılan hata terimlerini göstermektedir. $Z_{t}=\left[\sin \left(\frac{2 \pi k t}{T}\right), \cos \left(\frac{2 \pi k t}{T}\right)\right]^{\prime} \quad$ şeklinde trigonometrik terimleri içeren vektörü göstermektedir ki, burada yer alan $t$ trend terimini, $T$ gözlem sayısını, $k$ ise frekans değerini göstermektedir. Durağanlık temel hipotezini $\left(H_{0}: \sigma_{u}^{2}=0\right)$ sınamak için gerekli olan test istatistiğini hesaplamak amacıyla ilk aşamada Denklem 4 veya 5 'ten biri tahmin edilip, kalıntılar elde edilir (Pata, 2020).

$$
\begin{aligned}
& y_{t}=\alpha_{0}+\gamma_{1} \sin \left(\frac{2 \pi k t}{T}\right)+\gamma_{2} \cos \left(\frac{2 \pi k t}{T}\right)+e_{t} \\
& y_{t}=\alpha_{0}+\beta_{t}+\gamma_{1} \sin \left(\frac{2 \pi k t}{T}\right)+\gamma_{2} \cos \left(\frac{2 \pi k t}{T}\right)+e_{t}
\end{aligned}
$$

Denklem 4 ile düzey durağanlık boş hipotezi sınanırken, Denklem 5 ile trend durağanlık boş hipotezi sınanmaktadır. Test istatistiği Denklem 6 yardımıyla hesaplanmaktadır.

$$
\tau_{\mu}(k) \operatorname{or} \tau_{\tau}(k)=\frac{1}{T^{2}} \frac{\sum_{t=1}^{T} \widehat{S_{t}(k)^{2}}}{\widetilde{\sigma^{2}}}
$$

Optimal frekans değerini belirlemek için en küçük kalıntı kareler toplamını (KKT) veren değer seçilir. Veri yaratma sürecinin doğrusal olmayan trend içermemesi halinde, standart KPSS durağanlık testi, FKPSS durağanlık testine göre daha güçlüdür. Bu nedenle, Becker vd. (2006) çalışmasında doğrusal olmayan trendin yokluğunu gösteren temel hipotezi $\left(H_{0}: \gamma_{1}=\gamma_{2}=0\right)$ Denklem 7 'de belirtilen $\mathrm{F}$ test istatistiği ile sınamayı önermiştir (Yılancı, Aslan ve Özgür, 2018).

$$
F_{i}(k)=\frac{\left(S S R_{0}-S S R_{1}(k)\right) / 2}{S S R_{1}(k) /(T-q)}
$$

$S S R_{1}(\mathrm{k})$ Denklem 4 veya Denklem 5'ten elde edilen minimum kalıntı kareler toplamını; $S S R_{0}$ ise temel hipotezin geçerli olduğu regresyonun minimum kalıntı kareler toplamını ve $q$ ise bağımsız değişken sayısını ifade etmektedir. F istatistiği için gerekli kritik değerler Becker vd. (2006) makalesinde yer almaktadır.

\subsection{Fourier Shin Eşbütünleşme Testi}

Granger (1981) ve Engle ve Granger (1987) çalışmalarından bu yana ampirik literatürde değişkenler arasındaki uzun dönemli ilişkiyi tespit etmek amacıyla, eşbütünleşme testlerine büyük önem verilmiştir. Eşbütünleşme analizinin popülerliğine rağmen, birçok yöntem eşbütünleşme ilişkisinin olmadı̆̆ı boş hipoteze karşıık, alternatif hipotezde eşbütünleşme ilişkisinin varlığını test etmektedir. Bununla birlikte Phillips ve Ouliaris (1990) ile Shin (1994) boş hipotezde eşbütünleşme ilişkisinin varlığının test edilmesinin kavramsal olarak daha uygun olacağını iddia etmişlerdir. Ayrıca eşbütünleşme testleri değişkenler arasındaki uzun dönemli ilişkileri test ettiği için, geniş bir zaman aralığını içeren veri setlerinin kullanımı daha uygun olacaktır, ancak analiz yapılan veri setinin zaman aralığı uzadıkça ilişkilerin yapısal değişikliklere uğrama olasılığı da artacaktır. Bartley, Lee ve Strazicich (2001) çalışmasında da belirttiği üzere deterministik trenddeki mevcut bir kırılma dikkate alınmazsa, eşbütünleşme testinin uzun dönemli ilişkinin varlığını ifade eden boş hipotezi reddetme eğilimi olacaktır. Böyle bir problem ile baş edebilmek için, regresyona kukla değişken ekleyerek olası kırılma noktaları tespit edilmeye çalışılmaktadır. Carrion-i-Silvestre ve Sansó (2006) benzer bir yöntemi takip ederek hem deterministik terim hem de eşbütünleşme vektörlerinde tek bir kırılmaya izin vermiştir. Bununla birlikte test istatistiklerinin performansı sadece bir keskin kırılma varsayımına ve tahmini kırılma noktasının doğruluğuna bağlıdır. Bu önemli bir konudur çünkü gerçekte makroekonomik değişkenler, bilinmeyen sayı ve biçimde çok çeşitli yapısal kırılmalar gösterebilir. Keskin bir kırılma olması varsayımı sübjektif ve incelenen olguya yönelik spesifik bir yaklaşım olduğu için kırılmaları inmal etmek kadar büyük model yanlışlığına sebep olabilir (Tsong, Lee, Tsai ve Hu, 2016). 
Bu eksiklikleri gidermek amacıyla Tsong vd. (2016) tarafından Fourier fonksiyonu ile literatüre kazandırılan eşbütünleşme testi, literatürdeki birçok eşbütünleşme testinin aksine (Gregory ve Hansen, 1996; Johansen, Mosconi ve Nielsen, 2000; Hatemi-J, 2008) temel hipotezde eşbütünleşme ilişkisinin varlığını araştırmaktadır. Bu açıdan Fourier eşbütünleşme testi, yapısal değişimlerin formuna ve sayısına karşın güvenilir sonuçlar türetmektedir (Yılancı, 2017).

Tsong vd. (2016), Shin (1994) tarafından geliştirilen ve KPSS birim kök analizine dayalı ve boş hipotezde seriler arasındaki eş bütünleşik ilişkiyi inceleyen teste, Fourier trigonometrik fonksiyonlarını ekleyerek yapısı, sayısı ve zamanı bilinmeyen kırılmalara karşı güvenilir sonuçlar türeten Fourier Shin (FSHIN) eşbütünleşme testini geliştirmiştir.

FSHIN eşbütünleşme testinde Denklem 8' deki eşbütünleşme regresyonu dikkate alınmaktadır.

$$
y_{t}=d_{t}+x_{i}^{\prime} \beta+\eta_{t}, t=1,2,3, \ldots, T
$$

Denklem 8'de $\eta_{t}=\gamma_{t}+v_{1 t}, \gamma_{t}=\gamma_{t-1}+u_{t}, x_{t}=x_{t-1}+v_{2 t}$. Ayrıca $u_{t}$, sifır ortalama $\sigma_{u}^{2}$ varyans ile bağımsız, benzer dağılan hata terimini, $\gamma_{t}$ ise sıfır ortalama ile bir rassal yürüyüş sürecini göstermektedir. Denklem 8' de yer alan $d_{t}$ ise modelde sabit terim yer alırsa $d_{t}=\delta_{0}+f_{t}$, hem sabit terim hem de trend değeri yer alırsa $d_{t}=\delta_{0}+\delta_{1} t+f_{t}$ şeklinde tanımlanabilmektedir. Buradaki $f_{t}$, Fourier fonksiyonunu ifade etmektedir.

$$
f_{t}=\alpha_{k} \sin \left(\frac{2 k \pi t}{T}\right)+\beta_{k} \cos \left(\frac{2 k \pi t}{T}\right)
$$

Denklem 9'daki k Fourier frekans değerini, sin ve cos doğrusal olmayan terimleri, $t$ ve $T$ ise sırasıyla trend değeri ve gözlem sayısını ifade etmektedir. Analizde boş hipotez $H_{0}: \sigma_{u}^{2}=0$ (eşbütünleşme ilişkisinin varlığı), alternatif hipotez ise $H_{a}: \sigma_{u}^{2}>0$ (eşbütünleşme ilişkisinin yokluğu) şeklinde ifade edilmektedir.

Denklem 8 ve 9 eşitlikleri boş hipotez altında Denklem 10'daki gibi yeniden elde edilerek eşbütünleşme ilişkisinin analiz edildiği model kurulmaktadır.

$$
y_{t}=\alpha_{0}+\sum_{k=1}^{n} \alpha_{k} \sin \left(\frac{2 k \pi t}{T}\right)+\sum_{k=1}^{n} \beta_{k} \cos \left(\frac{2 k \pi t}{T}\right)+x_{t}^{\prime} \beta+v_{1 t}
$$

Denklem 10'daki n terimi, optimal frekans değerini göstermektedir. FSHIN test istatistiği Denklem 11 yardımıyla hesaplanmaktadır.

$$
C I_{f}^{m}=T^{-2} \widehat{\omega}_{1}^{2} \sum_{t=1}^{T} S_{t}^{2}
$$

Denklem 11'deki $S_{t}=\sum_{t=1}^{T} \widehat{v_{1} t}$ terimi, Denklem 10'dan elde edilen en küçük kareler hata terimlerinin kısmi toplamını, $\widehat{\omega}_{1}^{2}$ terimi ise $v_{1 t}$ teriminin uzun dönem varyansının tutarı tahmincisini göstermektedir.

\section{Ampirik Sonuçlar}

Çalışmada ilk olarak serilerin durağanlık seviyelerini belirlemek amacıyla Fourier KPSS durağanlık testine yer verilmektedir. Daha sonra serilerin durağanlık özelliklerine bağlı olarak seriler arasındaki uzun dönemli ilişkinin tespit edilmesi amacıyla Shin eşbütünleşme ve Fourier Shin eşbütünleşme testi uygulanacaktır. Çalışmada uzun dönem katsayılar ise Dinamik En Küçük Kareler (DOLS) tahmincisi aracılığıyla belirlenecektir. Son olarak seriler arasındaki nedensellik ilişkisini belirlemek adına Toda-Yamamoto nedensellik testine başvurulacaktır.

Tablo 2' de FKPSS durağanlık testi sonuçları yer almaktadır. Durağanlık testi sonuçlarına göre analize dahil edilen değişkenlerin tamamının \%5 anlamlılık düzeyinde seviyede durağan olmadığı tespit edilmiştir. Bu 
nedenle serilerin birinci fark değerleri için durağanlık analizleri gerçekleştirilmiş ve elde edilen bulgulara Tablo 3'te yer verilmiştir.

Tablo 2. FKPSS Test Sonuçları (Seviyede)

\begin{tabular}{|c|c|c|c|c|c|c|}
\hline Ülke & Seri & Frekans & MinKKT & FKPSS & F istatistiği & KPSS \\
\hline \multirow{5}{*}{ Brezilya } & $\ln Y$ & 1 & 0,273 & $0,310(4)$ & 35,242 & 0,659 \\
\hline & InK & 5 & 0,431 & $0,512(1)$ & 5,052 & 0,463 \\
\hline & InOPEN & 1 & 0.496 & $0,208(8)$ & 42,804 & 0,509 \\
\hline & InFD & 1 & 2,049 & $0,332(4)$ & 44,052 & 0,691 \\
\hline & $\mathrm{InHCl}$ & 1 & 0,604 & $0,399(4)$ & 26,737 & 0,746 \\
\hline \multirow{5}{*}{ Endonezya } & $\ln Y$ & 1 & 2,276 & $0,373(4)$ & 17,973 & 0,731 \\
\hline & InK & 2 & 0.347 & $0,652(3)$ & 35,391 & 0,920 \\
\hline & InOPEN & 1 & 0,573 & $0,251(2)$ & 16,409 & 0,540 \\
\hline & InFD & 3 & 0,912 & $1,096(1)$ & 7,714 & 0,801 \\
\hline & $\mathrm{InHCl}$ & 1 & 0,243 & $0,381(4)$ & 34,681 & 0,703 \\
\hline \multirow{5}{*}{$\begin{array}{l}\text { Güney } \\
\text { Afrika }\end{array}$} & $\ln Y$ & 1 & 0,023 & $0,221(3)$ & 290,98 & 1,064 \\
\hline & InK & 1 & 0,437 & $0,331(3)$ & 31,300 & 0,686 \\
\hline & InOPEN & 1 & 0,224 & $0,353(6)$ & 57,169 & 0,968 \\
\hline & InFD & 1 & 0,575 & $0,353(4)$ & 55,032 & 0,699 \\
\hline & $\operatorname{InHCl}$ & 1 & 0,218 & $0,394(4)$ & 35,779 & 0,708 \\
\hline \multirow{5}{*}{ Hindistan } & $\ln Y$ & 1 & 3,086 & $0,397(4)$ & 27,640 & 0,742 \\
\hline & InK & 1 & 0.311 & $0,223(4)$ & 43,246 & 1,637 \\
\hline & InOPEN & 1 & 1,787 & $0,325(4)$ & 79,278 & 0,674 \\
\hline & InFD & 1 & 0,283 & $0,287(1)$ & 34,209 & 0,569 \\
\hline & $\mathrm{InHCl}$ & 1 & 0,321 & $0,397(4)$ & 31,512 & 0,741 \\
\hline \multirow{5}{*}{ Türkiye } & $\ln Y$ & 1 & 1,721 & $0,388(4)$ & 18,956 & 0,742 \\
\hline & InK & 2 & 1,090 & $0,620(7)$ & 12,209 & 0,602 \\
\hline & InOPEN & 1 & 1,487 & $0,392(3)$ & 14,220 & 0,796 \\
\hline & InFD & 1 & 3,027 & $0,342(4)$ & 38,281 & 0,682 \\
\hline & $\ln \mathrm{HCl}$ & 1 & 0,318 & $0,401(9)$ & 19,262 & 0,756 \\
\hline
\end{tabular}

Not: Parantez içerisindeki değerler bant genişliğini göstermektedir. FKPSS testi için kritik değerler \%5 anlamlılık düzeyi ve $1,2,3$, 4 ve 5 frekans değerleri için sırasıyla $0,1720,0,4152,0,4480,0,4592$ ve $0,4626^{\prime}$ dır. Trigonometrik terimlerin anlamlıı̆̆ını test etmek amacıyla kullanılan F testi için kritik değerler ise \%5 anlamlılık düzeyinde 4,929'dur.

Tablo 3'te yer alan bulgular, analize dahil edilen tüm serilerin birinci fark değerlerinde durağan hale geldiklerini ortaya koymaktadır. Ayrıca çalışmada farkı alınan seriler için $F$ testleri de uygulanmış ve trigonometrik terimlerin anlamlı olduğu bulguları da elde edilmiştir. Buna göre ekonomik büyüme, sabit sermaye stoku, dışa açıklık, finansal gelişme ve insani gelişme endeksi serilerinin tamamının birinci fark değerlerinde durağan, diğer bir ifadeyle I(1), oldukları belirlenmiştir. Elde edilen bulgular, seriler arasında uzun dönemli ilişkinin varlığını araştırmaya imkan tanımaktadır. Bu doğrultuda çalışmada Fourier eşbütünleşme analizi gerçekleştirilmiştir. Elde edilen bulgular Tablo 4'te yer almaktadır.

Tablo 4, analize dahil edilen ülkeler için Shin eşbütünleşme ve Fourier Shin eşbütünleşme test sonuçlarını içermektedir. Tablo 4'te yer alan $\mathrm{F}$ istatistiği değerleri kritik değerlerden büyük olduğu için (Hindistan hariç) trigonometrik terimlerin anlamlı olduğu anlaşılmaktadır. Fourier Shin eşbütünleşme testi sonuçlarına göre hesaplanan test istatistikleri \%5 kritik değerlerden küçük olduğu için Brezilya, Hindistan, Güney Afrika ve Türkiye için eşbütünleşmenin varlığını ifade eden boş hipotez reddedilememektedir. Endonezya için ise Fourier Shin eşbütünleşme testine göre uzun dönemli ilişki elde edilememişken, Shin eşbütünleşme testi seriler arasında uzun dönemli ilişkinin bulunduğuna işaret etmektedir. Bu doğrultuda söz ülkelerin tamamı için uzun dönem katsayılar tahmin edilmiş ve elde edilen bulgulara Tablo 5'te yer verilmiştir. 
Çalışmada uzun dönem eşbütünleşme katsayıları, Stock ve Watson (1993) tarafından önerilen Dinamik En Küçük Kareler (DOLS) yöntemiyle tahmin edilmiştir.

Tablo 3. FKPSS Test Sonuçları (Birinci fark)

\begin{tabular}{|c|c|c|c|c|c|c|}
\hline & Seri & Frekans & MinKKT & FKPSS & $\mathrm{F}$ istatistiği & KPSS \\
\hline \multirow{5}{*}{ Brezilya } & $\Delta \ln Y$ & 2 & 0,033 & $0,242(1)$ & 2,434 & 0,178 \\
\hline & $\Delta \operatorname{lnK}$ & 5 & 0,272 & $0,130(6)$ & 2,439 & 0,110 \\
\hline & $\triangle \operatorname{lnOPEN}$ & 4 & 0,390 & $0,175(7)$ & 2,320 & 0,103 \\
\hline & $\Delta \operatorname{lnFD}$ & 1 & 0,360 & $0,144(9)$ & 1,094 & 0,111 \\
\hline & $\Delta \mathrm{lnHCl}$ & 1 & 0,001 & $0,140(3)$ & 15,770 & 0,088 \\
\hline \multirow{5}{*}{ Endonezya } & $\Delta \ln Y$ & 2 & 0,037 & $0,037(8)$ & 3,170 & 0,100 \\
\hline & $\Delta \operatorname{lnK}$ & 2 & 0,150 & $0,150(6)$ & 3,913 & 0,138 \\
\hline & $\triangle \mathrm{InOPEN}$ & 5 & 0,700 & $0,141(3)$ & 2,008 & 0,071 \\
\hline & $\Delta \operatorname{lnFD}$ & 3 & 0,448 & $0,135(2)$ & 1,811 & 0,166 \\
\hline & $\Delta \mathrm{lnHCl}$ & 1 & 0,001 & $1,351(7)$ & 12,722 & 0,415 \\
\hline \multirow{5}{*}{$\begin{array}{l}\text { Güney } \\
\text { Afrika }\end{array}$} & $\Delta \ln Y$ & 1 & 0,013 & $0,156(8)$ & 10,166 & 0,355 \\
\hline & $\Delta \operatorname{lnK}$ & 1 & 0,137 & $0,037(3)$ & 2,869 & 0,224 \\
\hline & $\triangle \operatorname{lnOPEN}$ & 4 & 0,238 & $0,189(9)$ & 1,928 & 0,166 \\
\hline & $\Delta \operatorname{lnFD}$ & 4 & 0,071 & $0,171(3)$ & 5,917 & 0,158 \\
\hline & $\Delta \mathrm{lnHCl}$ & 1 & 0,001 & $0,116(5)$ & 75,474 & 0,347 \\
\hline \multirow{5}{*}{ Hindistan } & $\Delta \ln Y$ & 1 & 0,011 & $0,139(0)$ & 4,134 & 0,431 \\
\hline & $\Delta \operatorname{lnK}$ & 2 & 0,074 & $0,190(3)$ & 3,401 & 0,350 \\
\hline & $\triangle$ InOPEN & 1 & 0,178 & $0,060(2)$ & 5,834 & 0,174 \\
\hline & $\Delta \operatorname{lnFD}$ & 4 & 0,127 & $0,137(2)$ & 2,566 & 0,069 \\
\hline & $\Delta \mathrm{lnHCl}$ & 1 & 0,001 & $0,046(3)$ & 11,551 & 0,313 \\
\hline \multirow{5}{*}{ Türkiye } & $\Delta \ln Y$ & 4 & 0,052 & $0,201(7)$ & 2,696 & 0,120 \\
\hline & $\Delta \operatorname{lnK}$ & 4 & 0,339 & $0,112(7)$ & 3,422 & 0,080 \\
\hline & $\triangle \mathrm{InOPEN}$ & 3 & 0,417 & $0,268(5)$ & 2,193 & 0,224 \\
\hline & $\Delta \operatorname{lnFD}$ & 3 & 0,381 & $0,186(5)$ & 3,447 & 0,124 \\
\hline & $\Delta \mathrm{lnHCl}$ & 2 & 0,01 & $0,249(4)$ & 8,819 & 0,266 \\
\hline
\end{tabular}

Not: Parantez içerisindeki değerler bant genişliğini göstermektedir. FKPSS testi için kritik değerler \%5 anlamlılık düzeyi ve $1,2,3$, 4 ve 5 frekans değerleri için sırasıyla $0,1720,0,4152,0,4480,0,4592$ ve 0,4626 ' dır. Trigonometrik terimlerin anlamlıı̆ı̆ını test etmek amacıyla kullanılan $\mathrm{F}$ testi için kritik değerler ise $\% 5$ anlamlılık düzeyinde 4,929'dur.

Tablo 4. SHIN ve FSHIN Eşbütünleşme Testi Sonuçları

\begin{tabular}{lccccc}
\hline & Min KKT & Frekans (k) & FSHIN & F-istatistiği & SHIN \\
\hline Brezilya & 0,016 & 1 & $0,038^{*}$ & 47,09 & $0,088^{*}$ \\
\hline Endonezya & 0,058 & 2 & 0,178 & 108,48 & $0,116^{*}$ \\
\hline Güney Afrika & 0,009 & 2 & $0,089^{*}$ & 300,22 & $0,097^{*}$ \\
\hline Hindistan & 0,016 & 1 & $0,049^{*}$ & 2,81 & 0,171 \\
\hline Türkiye & 0,034 & 1 & $0,056^{*}$ & 20,19 & 0,137 \\
\hline
\end{tabular}

Not: *; \%5 düzeyinde eşbütünleşme ilişkisinin varlığını göstermektedir. FSHIN testinde 1 ve 2 frekans değeri için \%5 anlamlılık düzeyinde kritik değerler sırasıyla 0,061 ve 0,097'dir. SHIN testi için \%5 anlamlılık düzeyinde kritik değer $0,121^{\prime}$ 'dir. F testi için \%5 anlamlılık düzeyinde kritik değer 4,066'dır. 
Tablo 5. Uzun Dönem Eşbütünleşme Katsayıları

\begin{tabular}{|c|c|c|c|c|c|}
\hline Ülke & InK & InOPEN & $\ln F D$ & $\mathrm{InHCl}$ & $\begin{array}{c}\text { Nedensellik } \\
\text { Bulguları }\end{array}$ \\
\hline Brezilya & $\begin{array}{c}0,706^{*} \\
(10,261)\end{array}$ & $\begin{array}{l}0,131^{*} \\
(3,750)\end{array}$ & $\begin{array}{c}0,008 \\
(0.309)\end{array}$ & $\begin{array}{c}0,911^{*} \\
(19,888)\end{array}$ & $\ln Y-\operatorname{lnFD}$ \\
\hline Endonezya & $\begin{array}{c}0,715^{*} \\
(23,817)\end{array}$ & $\begin{array}{c}0,924 * \\
(10,094)\end{array}$ & $\begin{array}{l}0,348^{*} \\
(5,959)\end{array}$ & $\begin{array}{l}0,610^{*} \\
(6,444)\end{array}$ & $\operatorname{lnFD} \rightarrow \ln Y$ \\
\hline Güney Afrika & $\begin{array}{c}0,393^{*} \\
(11,245)\end{array}$ & $\begin{array}{l}0,118^{*} \\
(6,548)\end{array}$ & $\begin{array}{c}0,116^{* *} \\
(2.840)\end{array}$ & $\begin{array}{l}0,329 * \\
(7,976)\end{array}$ & $\operatorname{lnFD} \rightarrow \ln Y$ \\
\hline Hindistan & $\begin{array}{c}-0,298 \\
(-1,337)\end{array}$ & $\begin{array}{c}0,090 \\
(1,193)\end{array}$ & $\begin{array}{c}0,458 * * \\
(2,795) \\
\end{array}$ & $\begin{array}{c}2,471^{*} \\
(12,098)\end{array}$ & $\ln Y-\operatorname{InFD}$ \\
\hline Türkiye & $\begin{array}{l}0,214^{*} \\
(3,623)\end{array}$ & $\begin{array}{l}0,150 * * \\
(2,159)\end{array}$ & $\begin{array}{l}0,158^{*} \\
(4,775)\end{array}$ & $\begin{array}{l}0,645^{*} \\
(3,131)\end{array}$ & $\ln Y-\operatorname{InFD}$ \\
\hline
\end{tabular}

Not: ${ }^{*}$ ve ${ }^{* *}$ işaretleri sırasıyla katsayıların \%1 ve \%5 düzeylerinde anlamlılı̆ı göstermektedir. Parantez içerisindeki değerler $t$ istatistik değerlerini ifade etmektedir. $(\rightarrow)$ işareti seriler arasında tek yönlü nedensellik ilişkisinin bulunduğuna, (-) işareti ise seriler arasında nedensellik ilişkisinin bulunmadığına işaret etmektedir.

Tablo 5'te yer alan bulgulara göre, finansal gelişme düzeyi Brezilya dışında yer alan dört ülkede (Endonezya, Güney Afrika, Hindistan ve Türkiye) pozitif ve istatistiksel olarak anlamlı katsayılara sahiptir. Buna göre finansal gelişme düzeyinde meydana gelecek \%1'lik bir artış ekonomik büyüme üzerinde Hindistan için yaklaşık \%0,45, Endonezya için yaklaşık \%0,34, Türkiye için yaklaşık \%0,15 ve son olarak Güney Afrika için yaklaşık \%0,11 oranında artış sağlamaktadır. Elde edilen bulgular finansal gelişme düzeyinin kırılgan ekonomilerin ekonomik performansları üzerinde önemli bir belirleyici olduğunu ortaya koymaktadır.

Finansal gelişme düzeyinin ekonomik büyüme üzerindeki pozitif etkilerinin önemli olduğu kabul edilmekle birlikte, modelde yer alan diğer değişkenlere kıyasla (genel olarak) daha küçük oranda etkilere sahip olduğu dikkat çekmektedir. Özellikle insani gelişme endeksinin tüm ülkelerin ekonomik büyüme performansları üzerindeki en önemli katkıyı sağlayan parametrelerden birisi olduğu anlaşılmaktadır. Buna göre insani gelişme endeksinde meydana gelecek \%1'lik bir artı̧̧ ekonomik büyüme üzerinde Hindistan için yaklaşık \%2,47, Brezilya için yaklaşık \%0,91, Türkiye için yaklaşık \%0,64, Endonezya için yaklaşık \%0,61 ve son olarak Güney Afrika için yaklaşık \%0,32 oranında artış sağlamaktadır.

Bununla birlikte kırılgan ekonomilerin büyüme performansları üzerinde sermaye stoku ve dışa açıklık parametrelerinin de oldukça önemli etkilere sahip olduğu dikkat çekmektedir. Buna göre sabit sermaye stokunda meydana gelecek \%1'lik bir artış ekonomik büyüme üzerinde Endonezya için yaklaşık \%0,71, Brezilya için yaklaşık \%0,70, Güney Afrika için yaklaşık \%0,39 ve Türkiye için yaklaşık \%0,21 oranında artış sağlamaktadır. Diğer taraftan dışa açıklık oranında meydana gelecek \%1'lik artış ise Endonezya için yaklaşık $\% 0,92$, Türkiye için yaklaşık \%0,15, Brezilya için yaklaşı \%0,13 ve Güney Afrika için ise \%0,11 oranında artışa imkan sağlamaktadır. Özellikle ekonomik küreselleşme sürecinin iki önemli parametresi olan finansal gelişme ve dış ticaret değişkenleri bir arada değerlendirildiğinde, küreselleşmenin kırılgan ekonomilerin büyüme performansları üzerinde genel olarak olumlu bir etkiye sahip olduğu sonucuna ulaşılmaktadır. Son olarak Hindistan'a ait sabit sermaye stoku ve dışa açıklık parametrelerinin ise istatistiksel olarak anlamlı etkilere sahip olmadığı bulgularına ulaşılmıştır.

Tablo 5'te ayrıca finansal gelişme ve ekonomik büyüme değişkenleri arasındaki nedensellik ilişkisini belirleme anlamında Toda-Yamamoto nedensellik analizi bulgularına da yer verilmektedir. Tablo 5 'in sağ sütununda yer alan bulgular iki farklı sonuca işaret etmektedir: (i) Endonezya ve Güney Afrika için finansal gelişme düzeyinden ekonomik büyümeye doğru tek yönlü nedensellik ilişkisi bulunmaktadır. (ii) Brezilya, Hindistan ve Türkiye için ekonomik büyüme ve finansal gelişme arasında herhangi bir nedensellik ilişkisi bulunmamaktadır. 


\section{Sonuç}

Finansal gelişme ve ekonomik büyüme arasındaki ilişkinin yönü ve doğasını belirlemeye yönelik olarak literatürde oldukça yoğun bir tartışma alanı bulunmaktadır. Temel olarak finansal gelişme düzeyinin ekonomik büyüme üzerinde destekleyici bir rol oynadığı kabul edilmekle birlikte, bu etkinin ülkelerin sahip olduğu finansal gelişme seviyeleri ve kalkınma düzeyleri gibi bazı önemli faktörlere bağlı olarak farklılık gösterebileceği de kabul edilmektedir. Bu anlamda literatürde yer alan bulgular, mevcut durumda ortak bir görüş birliğinin sağlanamadığını ortaya koymaktadır.

Bu çalışmada ise finansal gelişme düzeyinin ekonomik büyüme üzerindeki etkisi, Morgan Stanley tarafından gerçekleştirilen ülke sınıflandırmasından hareketle, kırılgan ekonomiler grubuna dahil beşülke için incelenmesi amaçlanmıştır. 1980-2017 dönemleri için yıllık gözlemlerin dahil edildiği çalışmada, serilerin durağanlık özelliklerini belirlemek adına Fourier KPSS durağanlık, uzun dönemli ilişkinin varlığını ortaya koymak adına Fourier eşbütünleşme ve uzun dönem katsayıları tespit etmek adına DOLS tahmincisinden yararlanılmıştır. Çalışmada ayrıca finansal gelişme ve ekonomik büyüme arasındaki nedensellik ilişkisini belirleme anlamında Toda-Yamamoto nedensellik analizine de başvurulmuştur.

Fourier KPSS durağanlık testinden elde edilen bulgular, beş ülkeye ait serilerin tamamının düzey değerlerinde durağan olmadıklarını ortaya koymaktadır. Birinci fark değerleri ile yapılan durağanlık analizlerinin ardından tüm serilerin I(1) düzeyinde durağan oldukları tespit edilmiş ve böylelikle uzun dönemli ilişkinin varlığını araştırmaya yönelik koşul sağlanmıştır. Bu doğrultuda gerçekleştirilen Fourier Shin eşbütünleşme testi Endonezya dışında yer alan dört ülke (Brezilya, Güney Afrika, Hindistan ve Türkiye) için, Shin eşbütünleşme testi ise Brezilya, Endonezya ve Güney Afrika için seriler arasında uzun dönemli bir ilişkinin varlığını ortaya koymaktadır. DOLS tahmincisinden elde edilen bulgular ise Endonezya, Güney Afrika, Hindistan ve Türkiye için finansal gelişmenin ekonomik büyüme üzerinde pozitif ve istatistiksel olarak anlamlı katsayılara sahip olduğuna işaret etmektedir. Uzun dönemli analiz sonuçları ayrıca insani gelişme endeksi parametresinin tüm ülkeler için pozitif ve istatistiksel olarak anlamlı katsayılara sahip olduğunu, bununla birlikte sermaye stoku ve dışa açıklık oranı parametrelerinin ise Hindistan dışındaki tüm ülkeler için yine pozitif ve istatistiksel olarak anlamlı katsayılara sahip olduğunu ortaya koymaktadır. Özellikle insani gelişme endeksinin söz konusu ülkelerin ekonomik büyüme süreçleri üzerindeki en önemli belirleyicilerden birisi olduğu tespit edilmiştir.

Uzun dönem analizlerden elde edilen bulgular, kırılgan ekonomiler için finansal gelişme düzeyinin ekonomik büyüme üzerinde önemli bir rol oynadığını ortaya koymaktadır. Özellikle Hindistan ve Endonezya için finansal gelişme düzeyine yönelik elde edilen katsayıların nispi büyüklüğü dikkat çekmektedir. Buna karşın elde edilen bulgulardan Güney Afrika ve Türkiye'nin ise finansal gelişme sürecinden diğer kırılgan ekonomiler kadar faydalanamadıkları anlaşılmaktadır. Bu ülkelerden Güney Afrika için finansal gelişme düzeyi parametresi mevcut değişkeler içerisindeki en düşük etkiyi göstermektedir. Bu durum söz konusu iki ülkenin finansal entegrasyon düzeylerini artırmaya yönelik politikaların uygulanma zorunluluğunu ortaya koymaktadır.

Her ne kadar finansal gelişme düzeyinin ekonomik büyüme üzerindeki etkilerine yönelik elde edilen bulgular kırılgan ekonomiler için olumlu bir sonuca işaret etse de, söz konusu ülkelerin sürdürülebilir ekonomik büyüme politikaları çerçevesinde uygulamaları gereken iki önemli yaklaşım bulunmaktadır. Bunlardan ilki, teknoloji ve yenilik gibi potansiyel yatırım fırsatlarına yönelik ihtiyaç duyulan yabancı sermayenin sağlanabilmesi için ülkelerin sahip oldukları finans piyasalarındaki entegrasyon seviyelerini arttırmaları gerekmektedir. İkinci olarak ise özellikle son yıllarda sıklıkla meydana gelen küresel şoklara karşı finansal piyasaların direncini artıracak reformların gerçekleştirilmesi vazgeçilmez bir öneme sahiptir. Bu doğrultuda, finansal piyasaların ekonomik büyüme üzerindeki katkısı ile birlikte dış şoklara karşı olan aşırı duyarlıığının da politika yapıcılar tarafından dikkat edilmesi ve planlamalarını buna yönelik olarak gerçekleştirmeleri oldukça önem arz etmektedir. 


\section{Beyan ve Açıklamalar (Disclosure Statements)}

1. Bu çalışmanın yazarları, araştırma ve yayın etiği ilkelerine uyduklarını kabul etmektedirler (The authors of this article confirm that their work complies with the principles of research and publication ethics).

2. Yazarlar tarafından herhangi bir çıkar çatışması beyan edilmemiştir (No potential conflict of interest was reported by the authors).

3. Bu çalışma, intihal tarama programı kullanılarak intihal taramasından geçirilmiştir (This article was screened for potential plagiarism using a plagiarism screening program).

\section{Son Notlar}

1. Söz konusu üç yaklaşımdan farklı olarak literatürde finansal gelişme ile ekonomik büyüme arasında herhangi anlamlı bir ilişkinin bulunmadığına (Chang, 2002; Dawson, 2003; Kar vd. 2011) veya finansal gelişmenin ekonomik büyümeyi negatif yönde etkilediğine (Ram, 1999; Nili ve Rastad, 2007) yönelik çalışmalarda bulunmaktadır.

\section{Kaynaklar}

Akinlo, A. E., \& Egbetunde, T. (2010). Financial development and economic growth: The experience of 10 sub-Saharan African countries revisited. The Review of Finance and Banking, 2(1), 17-28.

Anwar, S., \& Nguyen, L. P. (2011). Financial development and economic growth in Vietnam. Journal of Economics and Finance, 35(3), 348-360.

Arestis, P., Demetriades, P. O., \& Luintel, K. B. (2001). Financial development and economic growth: The role of stock markets. Journal of Money, Credit and Banking, 33(1), 16-41.

Asteriou, D., \& Spanos, K. (2019). The relationship between financial development and economic growth during the recent crisis: Evidence from the EU. Finance Research Letters, 28, 238-245.

Baliamoune-Lutz, M. (2008). Financial development and income in North Africa. International Advances in Economic Research, 14(4), 422-432.

Bartley, W. A., Lee, J., \& Strazicich, M. C. (2001). Testing the null of cointegration in the presence of a structural break. Economics Letters, 73(3), 315-323.

Becker, R., Enders, W., \& Lee, J. (2006). A stationarity test in the presence of an unknown number of smooth breaks. Journal of Time Series Analysis, 27(3), 381-409.

Bhattacharya, P. C., \& Sivasubramanian, M. N. (2003). Financial development and economic growth in India: 1970-1971 to 1998-1999. Applied Financial Economics, 13(12), 925-929.

Botev, J., Égert, B., \& Jawadi, F. (2019). The nonlinear relationship between economic growth and financial development: Evidence from developing, emerging and advanced economies. International Economics, 160, 313.

Caporale, G. M., Rault, C., Sova, A. D., \& Sova, R. (2015). Financial development and economic growth: Evidence from 10 new European Union members. International Journal of Finance \& Economics, 20(1), 48-60.

Carrion-i-Silvestre, J. L., \& Sansó, A. (2006). Testing the null of cointegration with structural breaks. Oxford Bulletin of Economics and Statistics, 68(5), 623-646.

Christopoulos, D. K., \& Tsionas, E. G. (2004). Financial development and economic growth: Evidence from panel unit root and cointegration tests. Journal of Development Economics, 73(1), 55-74.

Chadwick, M. G. (2019). Dependence of the "Fragile Five" and "Troubled Ten" emerging market financial systems on US monetary policy and monetary policy uncertainty. Research in International Business and Finance, 49, 251-268.

Chang, T. (2002). Financial development and economic growth in Mainland China: A note on testing demand-following or supply-leading hypothesis. Applied Economics Letters, 9(13), 869-873.

Chang, T., \& Caudill, S. B. (2005). Financial development and economic growth: The case of Taiwan. Applied Economics, 37(12), 1329-1335.

Colombage, S. R. (2009). Financial markets and economic performances: Empirical evidence from five industrialized economies. Research in International Business and Finance, 23(3), 339-348. 
Dawson, P. J. (2003). Financial development and growth in economies in transition. Applied Economics Letters, 10(13), 833-836.

Dawson, P. J. (2010). Financial development and economic growth: A panel approach. Applied Economics Letters, 17(8), 741-745.

Demetriades, P. O., \& Hussein, K. A. (1996). Does financial development cause economic growth? Time-series evidence from 16 countries. Journal of Development Economics, 51(2), 387-411.

Durusu-Ciftci, D., Ispir, M. S., \& Yetkiner, H. (2017). Financial development and economic growth: Some theory and more evidence. Journal of Policy Modeling, 39(2), 290-306.

Ehigiamusoe, K. U., \& Lean, H. H. (2018). Finance-growth nexus: New insights from the West African region. Emerging Markets Finance and Trade, 54(11), 2596-2613.

Engle, R. F., \& Granger, C. W. (1987). Co-integration and error correction: Representation, estimation, and testing. Econometrica: Journal of the Econometric Society, 251-276.

Ghirmay, T. (2004). Financial development and economic growth in Sub-Saharan African countries: Evidence from time series analysis. African Development Review, 16(3), 415-432.

Goldsmith, R. W. (1969) Financial Structure and Development, Yale University Press, New Haven, CT.

Gondo, J. (2009). Financial development and economic growth: Evidence from South Africa: 1970-1999. In Annual Western Cape Economics Postgraduate Student Conference. Stellenbosch.

Granger, C. W. (1981). Some properties of time series data and their use in econometric model specification. Journal of Econometrics, 16(1), 121-130.

Gregory, A. W., \& Hansen, B. E. (1996). Residual-based tests for cointegration in models with regime shifts. Journal of Econometrics, 70(1), 99-126.

Halicioglu, F. (2007). The financial development and economic growth nexus for Turkey (No. 06/2007). EERI Research Paper Series, Brussels, Belgium.

Hatemi-j, A. (2008). Tests for cointegration with two unknown regime shifts with an application to financial market integration. Empirical Economics, 35(3), 497-505.

Hayaloğlu, P. (2015). Kırılgan beşli ülkelerinde finansal gelişme ve ekonomik büyüme ilişkisi: Dinamik panel veri analizi. Ekonomik ve Sosyal Araştırmalar Dergisi, 11(1), 131-144.

Helhel, Y. (2018). Financial development and economic growth relationship: An analysis with credit based financial index. Business and Economics Research Journal, 9(4), 761-771.

Johansen, S., Mosconi, R., \& Nielsen, B. (2000). Cointegration analysis in the presence of structural breaks in the deterministic trend. The Econometrics Journal, 3(2), 216-249.

Kar, M., Nazlıoğlu, Ş., \& Ağır, H. (2011). Financial development and economic growth nexus in the MENA countries: Bootstrap panel granger causality analysis. Economic Modelling, 28(1-2), 685-693.

Kaya, E., Bektaş, E., \& Feridun, M. (2011). Stock market and banking sector development in Turkey: Do they have the same impact on economic growth? Economic Research-Ekonomska Istraživanja, 24(4), 65-74.

Lenka, S. K., \& Sharma, R. (2020). Re-examining the Effect of Financial Development on Economic Growth in India: Does the Measurement of Financial Development Matter? Journal of Asia-Pacific Business, 21(2), 124-142.

Levine, R. (1997). Financial development and economic growth: Views and agenda. Journal of Economic Literature, 35(2), 688-726.

Levine, R. (2005). Finance and growth: Theory and evidence. Handbook of Economic Growth, 1, 865-934.

Lucas, R. E. (1988). On the mechanics of economic development. Journal of Monetary Economics, 22 (1988), 3-42.

Moyo, C., Khobai, H., Kolisi, N., \& Mbeki, Z. (2018). Financial development and economic growth in Brazil: A Non-linear ARDL approach. Paper No: 85252, MPRA.

Nili, M., \& Rastad, M. (2007). Addressing the growth failure of the oil economies: The role of financial development. The Quarterly Review of Economics and Finance, 46(5), 726-740.

Nyasha, S., \& Odhiambo, N. M. (2015). Banks, stock market development and economic growth in South Africa: A multivariate causal linkage. Applied Economics Letters, 22(18), 1480-1485.

Pata, U. K. (2020). Is the COVID-19 Pandemic a Financial Disaster for G7 Countries? Evidence from a Fourier Cointegration Test. SSRN: https://ssrn.com/abstract=3603068, http://dx.doi.org/10.2139/ssrn.3603068 
Patrick, H. T. (1966). Financial development and economic growth in underdeveloped countries. Economic Development and Cultural Change, 14(2), 174-189.

Phillips, P. C., \& Ouliaris, S. (1990). Asymptotic properties of residual based tests for cointegration. Econometrica: Journal of the Econometric Society, 165-193.

Pradhan, R. P., Arvin, M. B., Hall, J. H., \& Nair, M. (2016). Innovation, financial development and economic growth in Eurozone countries. Applied Economics Letters, 23(16), 1141-1144.

Ram, R. (1999). Financial development and economic growth: Additional evidence. The Journal of Development Studies, 35(4), 164-174.

Robinson, J. (1952) The generalization of the general theory. In the generalisation of the general theory and other essays, Macmillan, London.

Sahay, R., Cihak, M., N’Diaye, P., Barajas, A., Bi, R., Ayala, D., Gao, Y., Kyobe, A., Nguyen, L., Saborowski, C., Svirydzenka, K., and Yousefi, S. R. (2015). Rethinking financial deepening: Stability and growth in emerging markets. Staff Discussion Notes, 15(8), 1-41.

Shahbaz, M., Rehman, I. U., \& Muzaffar, A. T. (2015). Re-visiting financial development and economic growth nexus: The role of capitalization in Bangladesh. South African Journal of Economics, 83(3), 452-471.

Shin, Y. (1994). A residual-based test of the null of cointegration against the alternative of no cointegration. Econometric Theory, 10(1), 91-115.

Singh, T. (2008). Financial development and economic growth nexus: A time-series evidence from India. Applied Economics, 40(12), 1615-1627.

Soedarmono, W., Hasan, I., \& Arsyad, N. (2017). Non-linearity in the finance-growth nexus: Evidence from Indonesia. International Economics, 150, 19-35.

Soytaş, U., \& Küçükkaya, E. (2011). Economic growth and financial development in Turkey: New evidence. Applied Economics Letters, 18(6), 595-600.

Stefani, P. (2007). Financial development and economic growth in Brazil: 1986-2006. Economics Bulletin, 3(69), 1-13.

Stern, N. (1989). The economics of development: A survey. The Economic Journal, 99(397), 597-685.

Stock, H. J., \& M. W. Watson, (1993). A Simple estimator of cointegrating vectors in higher order integrated systems. Econometrica, 61(4), 783-820.

Sumarni, L. (2019). Financial development and economic growth in Indonesia: An ARDL-Bounds testing approach. Economic Journal of Emerging Markets, 11(1), 89-96.

Tsong, C. C., Lee, C. F., Tsai, L. J., \& Hu, T. C. (2016). The Fourier approximation and testing for the null of cointegration. Empirical Economics, 51(3), 1085-1113.

Uddin, G. S., Sjö, B., \& Shahbaz, M. (2013). The causal nexus between financial development and economic growth in Kenya. Economic Modelling, 35, 701-707.

Yilanci, V. (2017). Petrol fiyatları ile ekonomik büyüme arasındaki ilişkinin incelenmesi: Fourier yaklaşımı. Ekonometri ve Istatistik Dergisi, (27), 51-57.

Yılancı, V., Aslan, M., \& Özgür, Ö. (2018). Testing the validity of PPP theory for African countries. Applied Economics Letters, 25(18), 1273-1277. 


\section{EKLER}

Tablo A1. Gayrisafi Yurtiçi Hasıla Büyüme Oranı (Yıllık \%)

\begin{tabular}{lccccccc}
\hline & $\mathbf{2 0 1 3}$ & $\mathbf{2 0 1 4}$ & $\mathbf{2 0 1 5}$ & $\mathbf{2 0 1 6}$ & $\mathbf{2 0 1 7}$ & $\mathbf{2 0 1 8}$ & $\mathbf{2 0 1 9}$ \\
\hline Brezilya & 3,00 & 0,50 & $-3,55$ & $-3,28$ & 1,32 & 1,32 & 1,14 \\
\hline Endonezya & 5,56 & 5,01 & 4,88 & 5,03 & 5,07 & 5,17 & 5,02 \\
\hline Güney Afrika & 2,49 & 1,85 & 1,19 & 0,40 & 1,41 & 0,79 & 0,15 \\
\hline Hindistan & 6,39 & 7,41 & 8,00 & 8,26 & 7,04 & 6,12 & 5,02 \\
\hline Türkiye & 8,49 & 5,17 & 6,09 & 3,18 & 7,47 & 2,83 & 0,88 \\
\hline
\end{tabular}

Kaynak: World Development Indicator.

Tablo A2. Enflasyon Oranı (Yıllık \%)

\begin{tabular}{lccccccc}
\hline & $\mathbf{2 0 1 3}$ & $\mathbf{2 0 1 4}$ & $\mathbf{2 0 1 5}$ & $\mathbf{2 0 1 6}$ & $\mathbf{2 0 1 7}$ & $\mathbf{2 0 1 8}$ & $\mathbf{2 0 1 9}$ \\
\hline Brezilya & 6,20 & 6,33 & 9,03 & 8,74 & 3,45 & 3,66 & 3,73 \\
\hline Endonezya & 6,41 & 6,39 & 6,36 & 3,53 & 3,81 & 3,20 & 3,03 \\
\hline Güney Afrika & 5,78 & 6,14 & 4,51 & 6,59 & 5,18 & 4,50 & 4,12 \\
\hline Hindistan & 10,91 & 6,35 & 5,87 & 4,94 & 2,49 & 4,86 & 7,66 \\
\hline Türkiye & 7,49 & 8,85 & 7,67 & 7,78 & 11,14 & 16,33 & 15,18 \\
\hline
\end{tabular}

Kaynak: World Development Indicator.

Tablo A3. Cari İşlemler Dengesi (GSYiH \%)

\begin{tabular}{llllllll}
\hline & $\mathbf{2 0 1 3}$ & $\mathbf{2 0 1 4}$ & $\mathbf{2 0 1 5}$ & $\mathbf{2 0 1 6}$ & $\mathbf{2 0 1 7}$ & $\mathbf{2 0 1 8}$ & $\mathbf{2 0 1 9}$ \\
\hline Brezilya & $-3,23$ & $-4,13$ & $-3,02$ & $-1,35$ & $-0,73$ & $-2,20$ & $-2,69$ \\
\hline Endonezya & $-3,19$ & $-3,09$ & $-2,04$ & $-1,82$ & $-1,59$ & $-2,94$ & $-2,72$ \\
\hline Güney Afrika & $-5,80$ & $-5,08$ & $-4,59$ & $-2,82$ & $-2,55$ & $-3,63$ & $-3,04$ \\
\hline Hindistan & $-2,65$ & $-1,34$ & $-1,07$ & $-0,53$ & $-1,44$ & $-2,42$ & $-0,94$ \\
\hline Türkiye & $-5,88$ & $-4,16$ & $-3,18$ & $-3,11$ & $-4,76$ & $-2,69$ & 1,15 \\
\hline
\end{tabular}

Kaynak: World Development Indicator.

Tablo A4. Bütçe Dengesi (GSYiH \%)

\begin{tabular}{llllllll}
\hline & $\mathbf{2 0 1 3}$ & $\mathbf{2 0 1 4}$ & $\mathbf{2 0 1 5}$ & $\mathbf{2 0 1 6}$ & $\mathbf{2 0 1 7}$ & $\mathbf{2 0 1 8}$ & $\mathbf{2 0 1 9}$ \\
\hline Brezilya & $-3,00$ & $-6,00$ & $-10,20$ & $-9,00$ & $-7,80$ & $-7,10$ & $-5,90$ \\
\hline Endonezya & $-2,30$ & $-2,25$ & $-2,58$ & $-2,46$ & $-2,51$ & $-1,76$ & $-2,20$ \\
\hline Güney Afrika & $-4,40$ & $-4,30$ & $-4,10$ & $-3,80$ & $-4,40$ & $-4,20$ & $-6,30$ \\
\hline Hindistan & $-4,48$ & $-4,10$ & $-3,87$ & $-3,49$ & $-3,46$ & $-3,34$ & $-4,59$ \\
\hline Türkiye & $-1,00$ & $-1,10$ & $-1,00$ & $-1,10$ & $-1,50$ & $-1,90$ & $-2,90$ \\
\hline
\end{tabular}

Kaynak: https://tradingeconomics.com/country-list/government-budget. 